\title{
Education Research: Understanding barriers to goals of care communication for neurology trainees
}

Tarini Goyal, MD, Brittany N. Hasty, MD, MHPE, Sylvia Bereknyei Merrell, DrPH, MS, and Carl A. Gold, MD, MS Neurology ${ }^{\circledR}$ 2019;93:362-366. doi:10.1212/WNL.0000000000007975

\author{
Correspondence \\ Dr. Goyal \\ tgoyal@stanford.edu
}

\begin{abstract}
Objective

To describe the perspectives of neurology residents regarding barriers to effective goals of care discussions and to identify residents' current and desired educational strategies to improve goals of care communication.
\end{abstract}

\section{Methods}

All neurology residents at our institution were invited to voluntarily participate in focus groups. Residents were organized into 3 focus groups by year of training. Moderators asked residents open-ended questions about current goals of care communication practice and ideas for improving the frequency and effectiveness of goals of care discussions. All responses were audiorecorded, transcribed, and de-identified. Transcripts of the focus groups were independently read and coded by members of the research team. We performed thematic analysis to identify and systematize relationships across coded data.

\section{Results}

Twenty out of 29 neurology residents participated in the focus groups. We identified 3 overarching domains impeding goals of care communication: patient factors, resident factors, and systems factors. Residents proposed specific desired strategies to address these 3 domains with the goal of improving the frequency and efficacy of goals of care communication. The desired strategies included receiving feedback from patients and families, developing resident-focused educational opportunities through direct observation and coaching, and systems changes by documenting goals of care discussions.

\section{Conclusions}

Neurology residents identify multiple barriers to effective goals of care communication and propose specific desired strategies for improvement. This detailed input from residents will be incorporated into future curricular interventions to improve confidence and skill in leading goals of care discussions. 
Neurology residents care for patients facing life-altering and lifelimiting diseases, so it is crucial that they are proficient in the principles of palliative care, including goals of care communication skills. ${ }^{1}$ The Accreditation Council for Graduate Medical Education requires neurology residents to demonstrate this knowledge of palliative care, including psychosocial support and counseling for patients and families-necessary to goals of care discussions. ${ }^{2}$ Importantly, a 2009 survey of neurology residents revealed poor knowledge in multiple domains of neuropalliative care, including documenting patients' medical decision-making capacity, which includes discussing their goals of care. ${ }^{3}$

Internal medicine residents have expressed a lack of comfort in their ability to lead goals of care conversations. ${ }^{4}$ Contributing factors may include inadequate formal training in communication or prognostication, infrequent feedback from attending physicians, and concerns about interfering with patients' relationships with their outpatient clinicians. ${ }^{5}$ Challenges unique to the field of neurology may include neurologists' consultant role and the incurable, progressive nature of many neurologic diseases.

Educational interventions to improve goals of care communication skills have been described previously, in neurology and other specialties. ${ }^{6-8}$ Performing a needs assessment of residents is a critical step of the curriculum development process, and "efforts should be guided by empiric needs assessments of target audiences to determine current perceptions (and misperceptions), knowledge gaps, attitudes, and self-perceived needs." One recent needs assessment survey suggests that while neurology program directors believe that it is extremely important for residents to receive training in communication skills, perceived residents' skills are substantially lower. ${ }^{9}$ The survey did not differentiate between communication types, or specify goals of care conversations directly, and importantly did not include the resident perspective.

In this study, we conduct a needs assessment using semistructured focus groups to capture the perspectives of neurology residents regarding barriers to effective goals of care discussions, identify residents' current and desired educational strategies, and inform educational interventions.

\section{Methods}

All adult and pediatric neurology residents at our institution were invited to voluntarily participate in focus groups. Focus groups were specifically chosen over individual interviews or surveys to collect a wide range of resident perspectives during regularly scheduled resident time and to provide an opportunity for shared, engaged discussion. The study was approved by the Stanford University Institutional Review Board as an exempt protocol.

Residents were organized into focus groups by year of training. Focus groups were conducted by clinical and nonclinical members of the research team who had no role in clinically supervising or evaluating residents. Experienced moderators asked residents open-ended questions regarding current goals of care communication practice, including beliefs about key skills, barriers, resources for improvement, and ideas for improving the frequency and effectiveness of goals of care discussions. Of note, at our institution there is no formal goals of care curriculum currently in place for neurology residents.

All responses were audiorecorded, transcribed verbatim, and de-identified. Transcripts of all focus groups were independently read and coded by 2 members of the research team using a qualitative coding software (Dedoose, Los Angeles, CA). The coders identified salient excerpts using codes, a qualitative strategy to label and link ideas within the data, and inductively developed the preliminary codebook, an organizing structure for the codes. ${ }^{10} \mathrm{~A}$ final codebook was developed after 2 additional rounds of iterative coding to adjudicate discrepancies in code application and incorporate the full range of resident perspectives. A Cohen pooled $\kappa$ of 0.7 was considered sufficient for consistent code application and was conducted on the finalized codebook across all 3 transcripts. Finally, we performed a thematic analysis to identify and systematize relationships across coded data. ${ }^{10}$

\section{Results}

Twenty out of 29 neurology residents voluntarily participated in 3 focus groups and $65 \%$ of participants were female. The groups were divided by training year $1(n=8 / 11)$, year $2(n=$ $7 / 10)$, and year 3 residents $(n=5 / 8)$. There was no significant difference in mean age among the 3 groups. The interrater reliability analysis of codebook application resulted in a pooled $\kappa$ of 0.77 .

We identified 3 overarching domains impeding effective goals of care discussion: (1) patient, (2) resident, and (3) systems factors (table 1). First, in the patient factors domain, residents believed that many neurology patients experience loss of their personhood-cognition, language, personality, identity. Residents expressed that neurologic disease is a "more difficult conversation or prognosis to have because you're dealing with ambiguous loss and fundamentally changing the soul of the person. I think it's inherently a more difficult disease process to deal with" (PGY2). Often, residents must rely heavily on surrogates to navigate decision-making throughout their disease course. Another resident noted: "Although [the patient] was very clearly DNR/DNI, this patient...couldn't really speak for herself. The 2 daughters had very different opinions of what she might have wanted...the patient was very distressed" (PGY2).

Second, in the resident factors domain, residents expressed a belief that communication is an intrinsic or "humanistic" skill that is hard to learn. Residents were often uncertain about patients' projected outcomes, both due to the frequently 
Table 1 Resident-identified challenges to effective goals of care communication

\begin{tabular}{|c|c|c|}
\hline & Challenges & Selected quotations \\
\hline \multirow{3}{*}{$\begin{array}{l}\text { Patient } \\
\text { factors }\end{array}$} & Loss of personhood & "The elephant in the room is if this person is going to be the person who she was before." (PGY3) \\
\hline & Family surrogacy & $\begin{array}{l}\text { "The family members felt a lot of guilt because they had been a part of the decision for her to have the } \\
\text { procedure. They kept wavering in whether they wanted additional interventions to attempt to have her } \\
\text { survive." (PGY2) }\end{array}$ \\
\hline & Multiple decision points & $\begin{array}{l}\text { "I think the difference is for neurology patients, maybe particularly for stroke, goals of care is not code } \\
\text { status. 'Do you want a feeding tube? Do you want to go to rehab? Do you want to go home?"' (PGY2) }\end{array}$ \\
\hline \multirow[t]{4}{*}{$\begin{array}{l}\text { Resident } \\
\text { factors }\end{array}$} & $\begin{array}{l}\text { Concept that communication is } \\
\text { an intrinsic skill }\end{array}$ & $\begin{array}{l}\text { "I think it's hard to teach that humanistic skill that you need to be good at goals of care conversations. I } \\
\text { think some people are just naturally better at leading these conversations than other people." (PGY3) }\end{array}$ \\
\hline & $\begin{array}{l}\text { Uncertainty about patient } \\
\text { outcomes }\end{array}$ & $\begin{array}{l}\text { "I think that makes it challenging from a resident standpoint when...you have an incomplete } \\
\text { understanding of what are the next steps available. And neurologic prognoses in general can be really } \\
\text { difficult to summarize, to anticipate." (PGY4) }\end{array}$ \\
\hline & $\begin{array}{l}\text { Relationship with primary } \\
\text { doctor }\end{array}$ & $\begin{array}{l}\text { "Often when we talk to the primary doctor, they say, 'Do what you think is right.' They kind of disengage." } \\
\text { (PGY3) }\end{array}$ \\
\hline & Consultant role & $\begin{array}{l}\text { "The consultant role is sometimes a hard position to be in because you have your own opinions based on } \\
\text { what you know or think the prognosis is, but the primary team says something different. Especially in } \\
\text { front of the family I can't say, 'No, you're saying something that isn't what we think."' (PGY4) }\end{array}$ \\
\hline \multirow[t]{3}{*}{$\begin{array}{l}\text { System } \\
\text { factors }\end{array}$} & $\begin{array}{l}\text { Lack of opportunity to lead } \\
\text { discussions }\end{array}$ & $\begin{array}{l}\text { "It's just like a lumbar puncture. We're all not very good at LPs after our fifth LP. And I feel like I've actually } \\
\text { led } 5 \text { to } 10 \text { goals of care discussions. And so why would I think I'm good when I've only done that few and } \\
\text { I'm only doing them sporadically?" (PGY3) }\end{array}$ \\
\hline & Lack of attending feedback & $\begin{array}{l}\text { "I feel like the attendings aren't always there. They are the only ones who would give you specific } \\
\text { constructive feedback on certain phrases you used or times you got into a mess in the conversation." } \\
\text { (PGY3) }\end{array}$ \\
\hline & Unclear expectations & $\begin{array}{l}\text { "Whose responsibility is it when it's a non-urgent concern? And then, when do you do that? Because as } \\
\text { with anything, this has to be triaged along with a million other things." (PGY4) }\end{array}$ \\
\hline
\end{tabular}

ambiguous course of neurologic illness and their own inexperience. One resident commented that

[With] goals of care conversations, there's a certain amount of expectation you have to be able to give the family of what's going to happen...it's really hard to know that when you don't have as much experience in the field, like how someone is going to recover from a stroke when you haven't seen a lot of poststroke patients yet. I think that has limited some of my initial goals of care discussions (PGY3).

Finally, in the system factors domain, residents had difficulty navigating differences of opinion and approach with other clinicians, such as outpatient providers or the inpatient primary team calling for neurologic consultation. Systems factors contributed to resident frustrations, mostly due to lack of oversight and feedback. Residents desired the autonomy to lead goals of care discussions, with direct observation by attending neurologists for targeted feedback.

What we do need more of is actually more chances and more of a venue to [have goals of care discussions] in front of our teams because we don't often get to or someone else will be talking instead of us. Whereas, I feel like this is the appropriate time for us to be training this skill. (PGY3)

Residents discussed current educational strategies (use of reference materials, observation of more experienced physicians, self-reflection, and soliciting feedback from observers) and requested more deliberate educational opportunities to improve their communication skills during goals of care discussions (table 2). Residents proposed options for desired strategies at each of the patient, resident, and system factors with the aim of improving the frequency and efficacy of goals of care communication. The self-reported strategies included engaging patient and family members in sharing their experiences and involving them in the feedback process, developing resident-focused educational opportunities through direct observation and coaching, and systems changes by documenting goals of care discussions.

\section{Discussion}

In this study, we used a single institution needs assessment to describe and analyze barriers to effective goals of care discussions from the perspective of neurology residents. Residents identified patient, trainee, and system factors, each of which offers the potential for targeted intervention. Though interventions to improve goals of care communication skills have previously been described in the literature, our study emphasizes understanding the gaps, attitudes, and self-perceived needs of the residents prior to designing and implementing such interventions. ${ }^{1,6-8}$

Using resident-conceived ideas for improvement, we developed practical next steps for improving residents' communication skills. To further explore patient factors, patients 
Table 2 Resident-described strategies to improve the efficacy of goals of care communication: Currently utilized and proposed by residents

\begin{tabular}{|c|c|}
\hline & Selected quotations \\
\hline \multicolumn{2}{|l|}{ Current strategies utilized by residents } \\
\hline Articles, apps, and pocket cards & $\begin{array}{l}\text { "I have an app that has cards for difficult situations and acronyms that you could use to try to move } \\
\text { conversations along." (PGY2) }\end{array}$ \\
\hline Direct observation of role models & "I just pick up the skills that I think the attending or whoever did well." (PGY4) \\
\hline Self-reflection & $\begin{array}{l}\text { "I've gone through quite an evolution. As an intern, I think I was a little more nihilistic and very aggressive as } \\
\text { far as like when patients were old, and it didn't look very good, to be very upfront about my own opinion. } \\
\text { But over time I've recognized that my own opinion is not right all the time." (PGY4) }\end{array}$ \\
\hline Seeking feedback from observers & $\begin{array}{l}\text { "Every time I try to lead [a family meeting], I always try to make sure that someone else is there with me so } \\
\text { that I can get feedback from them about what they would have done differently." (PGY2) }\end{array}$ \\
\hline \multicolumn{2}{|l|}{ Proposed strategies by residents } \\
\hline \multicolumn{2}{|l|}{ Patient and family engagement } \\
\hline Education to patient/family & $\begin{array}{l}\text { "There's a Stanford letter writing project [with] prompts for patients like, 'What are the things that you } \\
\text { value? What do you want your doctor to know?"' (PGY2) }\end{array}$ \\
\hline Feedback from patients & $\begin{array}{l}\text { "[lt would] be helpful to have patient or family feedback about how things went, too. Because I think } \\
\text { sometimes the way you think it went-like everyone was happy and smiling at the end-but they're } \\
\text { actually like just doing that because they're trying to be nice to you and they know you're a trainee." (PGY3) }\end{array}$ \\
\hline \multicolumn{2}{|l|}{ Resident education } \\
\hline Coaching/directed feedback & $\begin{array}{l}\text { "Afterwards we'll debrief and do some feedback on how it went, so know that's going to happen no matter } \\
\text { what and it's standardized." (PGY4) }\end{array}$ \\
\hline Leading more solo discussions & $\begin{array}{l}\text { "I got to do one notable goals of care discussion on my own. It was very helpful for me to be able to do that } \\
\text { without having someone to turn to when it got hard." (PGY2) }\end{array}$ \\
\hline $\begin{array}{l}\text { Expectations to discuss in patient sign- } \\
\text { out }\end{array}$ & $\begin{array}{l}\text { "[That should be] a more important part of handoffs to what has really truly been discussed and to not } \\
\text { accept, "Oh, I wasn't there for the conversation." (PGY2) }\end{array}$ \\
\hline \multicolumn{2}{|l|}{ Systems changes } \\
\hline $\begin{array}{l}\text { Documentation of discussion in } \\
\text { electronic medical records }\end{array}$ & $\begin{array}{l}\text { “There should actually be a little dropdown menu that says, 'Discussed with patient from prior POLST } \\
\text { [Physician Orders for Life Sustaining Treatment],' or, 'Discussed with family."' (PGY2) }\end{array}$ \\
\hline
\end{tabular}

and families will be interviewed regarding their current experiences with goals of care discussions, and we plan to conduct a similar thematic analysis, with translation to assessment of patient-level outcomes such as goalconcordant care. To address residents' communication and prognostic skills, we will develop and implement an interactive communication curriculum for residents using a combination of didactic and role-playing techniques. Finally, recognizing the importance of direct observation and feedback, we plan to implement a coaching program for neurology faculty to evaluate resident communication skills. Clinical coaching around communication skills has shown promising results in other specialty training programs. ${ }^{11}$ We will also explore the residents' role in "priming" patients to think about their goals of care, as this strategy has been demonstrated to increase the frequency of both goals of care conversations and goal-concordant care in internal medicine patients. ${ }^{12}$

These strategies are specific to our institution; other residency programs may evaluate current and desired educational strategies through a similar data collection process and adapt the results to local needs. This may include instituting greater resident autonomy by supporting more resident-led goals of care discussions and incorporating these conversations into patient sign-out workflow processes, or by adding documentation of conversation items in the EMR system.

Although we focused on neurology residents, it is likely that many of the findings are relevant to residents across medical disciplines. Furthermore, by limiting our focus to neurology residents, other key stakeholder perspectives, such as those from faculty educators and patients, were not captured in this study. Moving forward, employing a needs assessment prior to curricular implementation will allow residency programs to more precisely target their curricular interventions. Of the methods of qualitative data collection, focus groups may be particularly valuable when discussion among the participants is critical to understanding the beliefs and cultures that affect their attitudes and behaviors. ${ }^{13}$ With future curricular interventions incorporating resident input, trainees will gain confidence and competency in the fundamental skill of guiding neurology patients and their families through complex goals of care discussions. 


\section{Acknowledgment}

The authors thank Tresa McGranahan, MD, PhD, for serving as a focus group moderator.

\section{Study funding}

This study was supported by the Rathmann Family Foundation E4C Medical Education Fellowship in Patient-Centered Care awarded to Dr. Gold.

\section{Disclosure}

The authors report no disclosures relevant to the manuscript. Go to Neurology.org/N for full disclosures.

\section{Appendix Authors}

\begin{tabular}{|c|c|c|c|}
\hline Name & Location & Role & Contribution \\
\hline $\begin{array}{l}\text { Tarini } \\
\text { Goyal, MD }\end{array}$ & $\begin{array}{l}\text { Department of } \\
\text { Neurology and } \\
\text { Neurological Sciences, } \\
\text { Stanford University } \\
\text { School of Medicine, CA }\end{array}$ & Author & $\begin{array}{l}\text { Conceptualization of } \\
\text { study, data analysis, } \\
\text { drafting the } \\
\text { manuscript }\end{array}$ \\
\hline $\begin{array}{l}\text { Brittany } \\
\text { N. Hasty, } \\
\text { MD }\end{array}$ & $\begin{array}{l}\text { Goodman Surgical } \\
\text { Education Center, } \\
\text { Department of } \\
\text { Surgery, Stanford } \\
\text { University School of } \\
\text { Medicine, CA }\end{array}$ & Author & $\begin{array}{l}\text { Major role in the } \\
\text { acquisition of data, } \\
\text { revising the } \\
\text { manuscript for } \\
\text { intellectual content }\end{array}$ \\
\hline $\begin{array}{l}\text { Sylvia } \\
\text { Bereknyei } \\
\text { Merrell, } \\
\text { DrPH, MS }\end{array}$ & $\begin{array}{l}\text { Goodman Surgical } \\
\text { Education Center, } \\
\text { Stanford-Surgery } \\
\text { Policy Improvement } \\
\text { Research and } \\
\text { Education Center (S- } \\
\text { SPIRE), Department of } \\
\text { Surgery, Stanford } \\
\text { University School of } \\
\text { Medicine, CA }\end{array}$ & Author & $\begin{array}{l}\text { Major role in } \\
\text { conceptualization of } \\
\text { study, acquisition of } \\
\text { data, revising the } \\
\text { manuscript for } \\
\text { intellectual content }\end{array}$ \\
\hline $\begin{array}{l}\text { Carl A. } \\
\text { Gold, MD, } \\
\text { MS }\end{array}$ & $\begin{array}{l}\text { Department of } \\
\text { Neurology and } \\
\text { Neurological Sciences, } \\
\text { Stanford University } \\
\text { School of Medicine, CA }\end{array}$ & Author & $\begin{array}{l}\text { Conceptualization of } \\
\text { study, data analysis, } \\
\text { revising the } \\
\text { manuscript for } \\
\text { intellectual content }\end{array}$ \\
\hline
\end{tabular}

\section{References}

1. Creutzfeldt CJ, Kluger B, Kelly AG, et al. Neuropalliative care: priorities to move the field forward. Neurology 2018;91:217-226.

2. ACGME program requirements for graduate medical education in neurology. 2017. Available at: acgme.org/Portals/0/PFAssets/ProgramRequirements/180_neurology_2017-07-01.pdf. Accessed September 17, 2018.

3. Creutzfeldt CJ, Gooley T, Walker M. Are neurology residents prepared to deal with dying patients? Arch Neurol 2009;66:1427-1429.

4. Siddiqui MF, Holley JL. Residents' practices and perceptions about do not resuscitate orders and pronouncing death: an opportunity for clinical teaching. Am J Hosp Palliat Med 2011;28:94-97.

5. Lamas D, Rosenblum L. Freedom from the tyranny of choice: teaching the end-of-life conversation. N Engl J Med 2012;366:1655-1657.

6. Schuh LA, Biondo A, An A, et al. Neurology resident learning in an end-of-life/ palliative care course. J Palliat Med 2007;10:178-181.

7. $\quad$ Chung H, Oczkowski SJW, Hanvey L, Mbuagbaw L, You JJ. Educational interventions to train healthcare professionals in end-of-life communication: a systematic review and meta-analysis. BMC Med Educ 2016;16:131.

8. Khot S, Billings M, Owens D, Longstreth WT. Coping with death and dying on a neurology inpatient service: death rounds as an educational initiative for residents. Arch Neurol 2011;68:1395-1397.

9. Mehta AK, Najjar S, May N, Shah B, Blackhall L. A needs assessment of palliative care education among the United States Adult Neurology Residency Programs. J Palliat Med 2018;21:1448-1457.

10. Creswell JW, Plano CVL. 30 Essential Skills for the Qualitative Researcher. Thousand Oaks, CA: SAGE Publications; 2016.

11. Rassbach CE, Blankenburg R. A novel pediatric residency coaching program: outcomes after one year. Acad Med 2018;93:430-434.

12. Curtis JR, Downey L, Back AL, et al. Effect of a patient and clinician communicationpriming intervention on patient-reported goals-of-care discussions between patients with serious illness and clinicians: a randomized clinical trial. JAMA Intern Med 2018; 178:930-940.

13. Stalmeijer RE, McNaughton N, Van Mook WNKA. Using focus groups in medical education research: AMEE Guide No. 91. Med Teach 2014;36:923-939.

\section{Committed to Making a Difference: 2020 American Academy of Neurology Research Program}

The American Academy of Neurology (AAN) is committed to making a profound difference in the lives of researchers, in turn making a difference in the lives of patients with brain disease. The ambitious 2020 AAN Research Program offers opportunities ranging from $\$ 130,000$ to $\$ 450,000$ and is designed for all types of research across all career levels and discovery stages. Pave your own pathway to patient care by applying for one of the opportunities by the October 1, 2019, deadline.

Visit AAN.com/view/ResearchProgram today. 


\section{Neurology}

\section{Education Research: Understanding barriers to goals of care communication for neurology trainees}

Tarini Goyal, Brittany N. Hasty, Sylvia Bereknyei Merrell, et al. Neurology 2019;93;362-366

DOI 10.1212/WNL.0000000000007975

This information is current as of August 19, 2019

Updated Information \&
Services
References
Citations
Subspecialty Collections
Permissions \& Licensing
Reprints

\section{Updated Information \&}

References

\section{Citations}

\section{Subspecialty Collections}

Reprints including high resolution figures, can be found at: http://n.neurology.org/content/93/8/362.full

This article cites 11 articles, 1 of which you can access for free at: http://n.neurology.org/content/93/8/362.full\#ref-list-1

This article has been cited by 2 HighWire-hosted articles: http://n.neurology.org/content/93/8/362.full\#\#otherarticles

This article, along with others on similar topics, appears in the following collection(s):

\section{All Education}

http://n.neurology.org/cgi/collection/all_education

Information about reproducing this article in parts (figures,tables) or in its entirety can be found online at:

http://www.neurology.org/about/about_the_journal\#permissions

Information about ordering reprints can be found online:

http://n.neurology.org/subscribers/advertise

Neurology ${ }^{\circledR}$ is the official journal of the American Academy of Neurology. Published continuously since 1951, it is now a weekly with 48 issues per year. Copyright () 2019 American Academy of Neurology. All rights reserved. Print ISSN: 0028-3878. Online ISSN: 1526-632X.

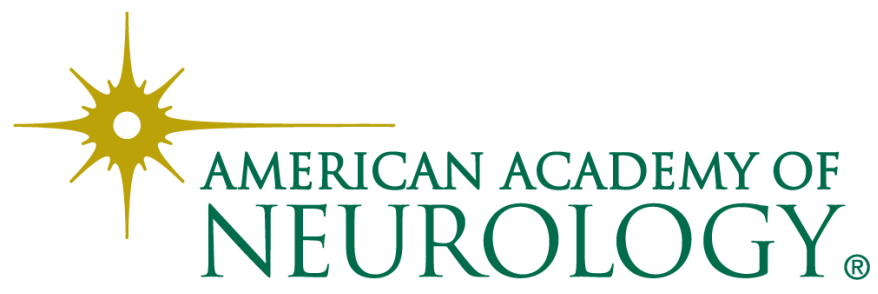

